\title{
PENGARUH PENAMBAHAN LIMBAH KULIT PISANG KEPOK (Musa paradisiaca Linn) DALAM PEMBUATAN KERUPUK
}

\section{THE EFFECT OF ADDITION OF KEPOK BANANA PEEL WASTE (Musa paradisiaca Linn) IN MAKING CRACKERS}

\author{
Siti Halija Sogo ${ }^{1)}$, Irianti Kurniasari ${ }^{2)}$, Sutoyo $^{2)}$ \\ 1) Mahasiswa Sekolah Tinggi Penyuluhan Pertanian Malang \\ ${ }^{2)}$ Dosen Sekolah Tinggi Penyuluhan Pertanian Malang \\ e-mail: kurnia_saree@yahoo.com
}

\begin{abstract}
ABSTRAK
Pisang merupakan salah satu komoditas pangan nasional. Pisang pada umumnya hanya dikonsumsi buahnya saja, sedangkan kulit pisang masih menjadi limbah pertanian. Kulit pisang memiliki kandungan karbohidrat dalam bentuk pati sebesar $18,5 \%$ yang dapat dimanfaatkan sebagai bahan baku olahan kerupuk. Penelitian ini bertujuan untuk mengetahui pengaruh penambahan pati limbah kulit pisang terhadap rasa, warna, dan tekstur kerupuk kulit pisang menggunakan uji sensoris. Penelitian ini menggunakan Rancangan Acak Kelompok (RAK) dengan penambahan kulit pisang sebagai perlakuan terdiri dari $\mathrm{P} 1=100$ gram, $\mathrm{P} 2=75$ gram, $\mathrm{P} 3=$ 50 gram, P4= 25 gram dengan masing-masing perlakuan ditambah 100 gram tepung tapioka. Parameter yang diamati adalah rasa, warna dan tekstur kerupuk kulit pisang melalui uji sensoris dengan menggunakan skala kesukaan terhadap 25 panelis. Data yang diperoleh dianalisis dengan analisis varian, jika terdapat perbedaan yang nyata maka dilanjutkan dengan uji BNT taraf 5\%. Hasil uji sensoris menggunakan skala kesukaan menunjukkan bahwa kerupuk kulit pisang yang paling disukai panelis yaitu kerupuk kulit pisang dengan penambahan 75 gram kulit pisang. Penambahan 75 gram kulit pisang menghasilkan warna yang lebih cerah, rasa yang lebih enak dan gurih, serta tekstur yang kenyal dan lembut sehingga lebih disukai oleh panelis.
\end{abstract}

Kata kunci : kulit pisang, pati, kerupuk, uji sensoris

\section{ABSTRACT}

Banana is one of national food commodities. Generally, the banana is consumed only by the fruit, while banana peel are still become waste. Banana peel has a carbohydrate content in the form of starch at 18.5\%, that can be used as a raw material in the processing of crackers. This study aimed to determine the effect of starch from banana peel through the taste, color, and texture of banana peel crackers using sensory test. Randomized Block Design used in this research with the addition of banana peel as a treatment consists of $P 1=100$ grams, $P 2=75$ grams, $P 3=50$ grams, $P 4=25$ grams and each treatment was added 100 grams of tapioca flour. The taste, color, and texture of banana peel crackers were observed through sensory test using a preference scale for 25 panelists. The data were analyzed by analysis of variance if there were significant differences continued by BNT 5\%. The sensory test results using a preference scale showed that the banana peel crackers were the most preferred by panelists is 75 grams of the addition of banana peel. The addition of 75 grams of banana peel had a brighter color, delicious and savory taste, also chewy and soft texture which is preferred by panelists. 
Keyword: banana peel, starch, crackers, sensory test

\section{PENDAHULUAN}

Sektor pertanian mempunyai peranan penting dalam pemenuhan kebutuhan pangan Indonesia. Dalam sektor pertanian dari mulai kegiatan budidaya sampai kegiatan pasca panen dapat menghasilkan bahan pangan. Pisang merupakan salah satu komoditas dalam sektor pertanian yang mampu memenuhi kebutuhan akan pangan nasional, karena selain sebagai konsumsi rumah tangga juga dapat sebagai bahan baku dalam industri pangan. Terdapat 3 provinsi yang memiliki luas areal tanam pisang terbesar di Indonesia yaitu Jawa Timur, Jawa Barat, dan Lampung. Pulau Jawa memberikan kontribusi produktivitas pisang paling besar dalam kurun waktu 33 tahun yaitu dari tahun 1980 2013 sebesar $61,22 \%$ dari total produksi pisang Indonesia (Hidayati dan Suhartini, 2018). Pisang pada umumnya hanya dikonsumsi buahnya saja. Kulit pisang kebanyakan masih menjadi limbah pertanian yang dibuang sehingga sering menimbulkan pencemaran lingkungan.

Kulit pisang memiliki kandungan karbohidrat berbentuk pati yang cukup tinggi, yaitu 18,5\% (Agustina, 2015). Pati limbah kulit pisang telah terbukti dapat digunakan sebagai bahan substituen tepung terigu dalam pembuatan mie dengan kemampuan substitusinya sebesar 20\% (Noviagustin et al., 2008). Selain pati, kulit pisang juga mengandung protein, lemak, kalsium, vitamin B dan C (Julfan et al., 2016). Dengan adanya berbagai kandungan gizi dalam kulit pisang, maka kulit pisang dapat diolah menjadi produk konsumsi lain seperti dodol, selai, sirup, keripik, serta kerupuk pisang. Pemanfaatan kulit pisang sebagai olahan kerupuk mempunyai beberapa fungsi diantaranya: dapat menambah variasi kerupuk yang telah beredar dikalangan masyarakat Indonesia, meningkatkan nilai ekonomi, melengkapi keanekaragaman bahan pangan, dan mningkatkan pendapatan masyarakat khususnya industri rumah tangga (Pary et al., 2016).

Kerupuk sebagai salah satu produk industri pangan harus memiliki standar mutu yang telah ditetapkan oleh Departemen Perindustrian. Menurut SNI 01-2713-1992, kriteria mutu kerupuk dapat ditinjau dari aspek sifat fisik yang meliputi warna, aroma, rasa dan tekstur. Kerupuk yang baik memiliki warna kuning kecokelatan. Aroma kerupuk didapat dari bahan yang digunakan, yang memberikan aroma tersendiri. Rasa kerupuk yang baik adalah gurih dan sesuai dengan bahan yang digunakan dalam pembuatan kerupuk. Tekstur kerupuk yang baik adalah renyah, volume mengembang dan memiliki penampakan yang menarik. Naf'an, (2012) melaporkan bahwa penambahan $25 \%$ kulit pisang mempunyai hasil uji sensoris tertinggi pada parameter rasa, warna, tekstur, dan aroma kerupuk kulit pisang.

Penelitian ini bertujuan untuk mengetahui pengaruh penambahan pati limbah kulit pisang terhadap rasa, warna, dan tekstur kerupuk kulit pisang menggunakan uji sensoris.

\section{METODE PENELITIAN}

\section{Alat dan Bahan}

Alat yang digunakan dalam penelitian ini adalah timbangan, blender, baskom plastik, nampan, panci, dandang, kompor, wajan, pisau, dan gunting. Bahan yang digunakan adalah kulit pisang kepok, air, kapur, tepung tapioka, tepung terigu, bawang putih, garam dan minyak goreng.

\section{Rancangan Penelitian}

Rancangan percobaan dalam penelitian ini menggunakan RAK (Rancangan Acak Kelompok) dengan empat perlakuan. Setiap perlakuan diulang sebanyak 6 kali sehingga diperoleh 24 satuan percobaan. Perlakuan dalam penelitian ini adalah sebagai berikut : 
P1 : 100 gram kulit pisang dan 100 gram tepung tapioka

P2 : 75 gram kulit pisang dan 100 gram tepung tapioka

P3 : 50 gram kulit pisang dan 100 gram tepung tapioka

P4 : 25 gram kulit pisang dan 100 gram tepung tapioka

\section{Pembuatan kerupuk dari kulit pisang}

Kulit pisang yang mau digunakan dicuci hingga bersih, kemudian direndam dengan air kapur selama \pm 20 menit. Kulit pisang direbus hingga lunak. Setelah lunak, kulit pisang diangkat dan didinginkan kemudian di potong-potong dengan ukuran yang kecil untuk mempermudah proses penghalusan dan pencampuran bahan. Kulit pisang yang telah direbus dicampur bawang putih dan garam kemudian dihaluskan menggunakan blender. Adonan dipisah pisahkan dan di timbang sesuai dengan perlakuan yaitu 25, 50, 75 dan 100 gram. Setiap perlakuan dicampur dengan tepung tapioka masing - masing sebanyak 100 gram. Adonan kulit pisang dan tepung tapioka yang sudah tercampur rata di masukan ke dalam plastik untuk dilakukan pengukusan. Pengukusan dilakukan \pm 40 menit. Adonan yang sudah dikukus setelah itu diangkat dan didinginkan \pm 5 jam. Setelah itu adonan di iris tipis - tipis dengan ukuran 2-3 mm. Adonan yang sudah diris tersebut di jemur di panas matahari selama \pm 8 jam yang selanjutnya disebut kerupuk kulit pisang. Kerupuk yang sudah kering kemudian digoreng di disajikan kepada panelis untuk diuji sensoris.

\section{Uji Sensoris dan Analisa Data}

Uji sensoris dilakukan terhadap rasa, warna, dan tekstur kerupuk kulit pisang berdasarkan tingkat kesukaan panelis. Panelis yang digunakan untuk menguji kerupuk kulit pisang sebanyak 25 panelis. Sampel disajikan secara acak pada panelis untuk memberikan nilai berdasarkan kriteria seperti tabel 1 dibawah ini:

79 | Jurnal Agriekstensia Vol. 17 No. 1 Juli 2018
Tabel 1. Kriteria penilaian panelis dalam uji kesukaan

\begin{tabular}{lc}
\multicolumn{1}{c}{ Skala Kesukaan } & Skala Numerik \\
Sangat tidak suka & 1 \\
Tidak suka & 2 \\
Kurang suka & 3 \\
Suka & 4 \\
Sangat Suka & 5 \\
\hline
\end{tabular}

Data yang diperoleh diolah menggunakan analisis ragam untuk mengetahui perbedaan pengaruh tiap perlakuan, jika terdapat perbedaan nyata maka dilanjutkan dengan uji BNT dengan taraf 5\%.

\section{HASIL DAN PEMBAHASAN}

Food and Agriculture Organization memperkirakan setiap tahunnya 1,3 ton buahbuahan berakhir menjadi sampah dan terbuang begitu saja. Pemanfaatan limbah kulit pisang menjadi olahan kerupuk merupakan salah satu teknologi zero waste untuk mengatasi permasalahan tentang sampah. Zero waste adalah cara mengolah semua bagian dari bahan masakan seoptimal mungkin tanpa ada bagian yang terbuang, apalagi jika bahan tersebut mempunyai kandungan gizi yang tinggi seperti kulit pisang. Menurut Pary et al., (2016) kulit pisang kepok matang yang telah direbus memiliki kandungan gizi yang dapat dilihat pada tabel 2 dibawah ini :

Tabel 2. Analisis kandungan gizi kulit pisang

\begin{tabular}{lc}
\multicolumn{2}{c}{ kepok } \\
\hline Kandungan gizi & Nilai $(\%)$ \\
\hline karbohidrat & 11,27 \\
protein & 1,71 \\
lemak & 3,28 \\
vitamin C & 0,30 \\
\hline
\end{tabular}

\section{Uji Sensoris rasa}

Hasil analisis statistik menunjukkan bahwa terdapat perbedaan yang nyata antar perlakuan terhadap kesukaan rasa kerupuk kulit pisang (Tabel 3). Perlakuan kulit pisang (P2) mempunyai rasa yang lebih disukai oleh panelis di bandingkan perlakuan lain. 
Penambahan 75 gram kulit pisang rasanya lebih enak dan lebih gurih, sehingga penginderaan rasa panelis menonjol pada perlakuan tersebut. Rasa merupakan respon lidah terhadap rangsangan suatu makanan yang merupakan salah satu faktor penting yang mempengaruhi tingkat penerimaan panelis terhadap suatu produk makanan (Zura, 2006).

Tabel 3. Hasil uji sensoris parameter rasa kerupuk kulit pisang

\begin{tabular}{lc}
\hline \multicolumn{1}{r}{ Perlakuan } & Rata - rata \\
\hline P1 & $2,83^{\mathrm{a}}$ \\
P2 & $3,05^{\mathrm{c}}$ \\
P3 & $2,93^{\mathrm{b}}$ \\
P4 & $2,91^{\mathrm{b}}$ \\
\hline
\end{tabular}

Menurut Winarno, (2004) rasa dipengaruhi oleh beberapa faktor yaitu senyawa kimia, suhu, konsentrasi dan interaksi dengan komponen rasa lain yaitu komponen rasa primer.

\section{Uji Sensoris warna}

Hasil analisis statistik menunjukkan bahwa terdapat perbedaan yang nyata antar perlakuan terhadap kesukaan warna kerupuk kulit pisang yang dapat dilihat pada tabel 4 . Penambahan 25 gram kulit pisang (P4) memberikan warna coklat yang lebih cerah dibandingkan perlakuan yang lain. Warna suatu bahan makanan dapat menentukan tingkat kesukaan panelis. Hal ini didukung pernyataan Winarno, (1997) bahwa suatu bahan pangan yang mempunyai gizi tinggi dan enak sekalipun tidak dapat digunakan apabila warnanya tidak bagus dipandang.

Tabel 4. Hasil uji sensoris parameter warna kerupuk kulit pisang

\begin{tabular}{lc}
\hline Perlakuan & Rata - rata \\
\hline P1 & $2,76^{\mathrm{a}}$ \\
P2 & $2,71^{\mathrm{a}}$ \\
P3 & $3,15^{\mathrm{b}}$ \\
P4 & $3,50^{\mathrm{c}}$ \\
\hline
\end{tabular}

Warna coklat pada kerupuk kulit pisang yang timbul disebabkan oleh adanya reaksi maillard yaitu reaksi yang terjadi antara 80 | Jurnal Agriekstensia Vol. 17 No. 1 Juli 2018 karbohidrat (pati) dan asam amino (Yasin, 2018).

\section{Uji sensoris tekstur}

Hasil analisis statistik menunjukkan bahwa penambahan kulit pisang 100 gram (P1) mempunyai perbedaan yang nyata di bandingkan perlakuan yang lain (Tabel 5). Penambahan kulit pisang 100 gram (P1) mempunyai tekstur yang kenyal dan lembut sehingga lebih banyak disukai oleh panelis. Hal ini sesuai dengan pendapat Purwati, (2007) bahwa kualitas tekstur sangat berkaitan erat dengan kekenyalan makanan, selain itu tekstur menjadi penting untuk diperhatikan karena erat hubungannya dengan penerimaan konsumen.

Tabel 5. Hasil uji sensoris parameter tekstur kerupuk kulit pisang

\begin{tabular}{lc}
\hline Perlakuan & Rata - rata \\
\hline P1 & $3,33^{\mathrm{c}}$ \\
P2 & $3,22^{\mathrm{b}}$ \\
P3 & $3,20^{\mathrm{b}}$ \\
P4 & $3,13^{\mathrm{a}}$ \\
\hline
\end{tabular}

Semakin sedikit kandungan pati dari tepung pisang dibandingkan tepung tapioka dari suatu adonan bahan, maka akan menyebabkan kadar air bahan tersebut menurun (Yasin, 2018). Seperti diketahui pati kulit pisang bersifat menyerap air. Menurut Breemer et al., (2010), pati kulit pisang yang mengalami pemanasan dengan keberadaan cukup banyak air, menyebabkan pati yang terkandung akan menyerap air dan membentuk pasta yang kental dan pada saat dingin membentuk masa yang kenyal dan liat.

\section{KESIMPULAN}

Kerupuk kulit pisang yang terpilih adalah kerupuk kulit pisang yang disukai panelis berdasarkan parameter rasa yaitu penambahan 75 gram kulit pisang. Penambahan 75 gram kulit pisang menghasilkan warna yang lebih cerah, rasa yang lebih enak dan gurih, serta tekstur yang kenyal dan lembut. 


\section{SARAN}

Penelitian berikutnya dilanjutkan dengan melihat masa simpan dari kerupuk kulit pisang kepok yang dihasilkan.

\section{DAFTAR PUSTAKA}

Agustina, MW. 2015. Pengaruh substitusi tepung kulit pisang raja (Musa paradisiaca) terhadap kualitas ledre. Skripsi. Semarang: Fakultas Teknik Universitas Negeri Semarang

Anggrainy, NH. 2016. Kajian karakteristik kerupuk kulit pisang ambon (Musa paradisiaca L) yang diperkaya dengan penambahan tepung kacang koro pedang (Cannavalia ensiformis). Skripsi. Bandung: Fakultas Teknik. Universitas Pasundan

Breemer, Polnaya dan Rumarupute. 2010. Pengaruh konsentrasi tepung beras ketan terhadap mutu dodol pala. Jurnal Budidaya Pertanian, 6(1): 17-20.

Emaga, TH, Andrianaivo, RH, Wathelet B, Tchango, JT. Paquot M. 2007. Effects of the stage of maturation and varieties on the chemical composition of banana and plantain peels, Food Chemistry.

Hidayati, TN dan Suhartini. 2018. Analisis daya saing ekspor pisang (Musa Paradiaca L.) Indonesia di pasar Asean dalam menghadapi Masyarakat Ekonomi Asean (MEA). Jurnal Ekonomi Pertanian dan Agribisnis (JEPA), 2(4): 267-278

Julfan., Harun, N., dan Rahmayuni. 2016.Pemanfaatan kulit pisang kepok (Musa paradisiaca Linn) dalam pembuatan dodol. Jurnal Teknologi Pertanian 3(2) : 1-12
Naf'an. 2012. Proses Produksi Kerupuk Kulit Pisang. Laporan Tugas Akhir DIII. Surakarta: Universitas Sebelas Maret.

Noviagustin, L, Riin SY, dan Utin FY. 2008. Pemanfaatan limbah kulit pisang sebagai substituen tepung terigu dalam pembuatan

mie. https://dokumen.tips/documents/k ulit-pisang.html. diakses tgl 31 Januari 2019.

Pary, C., Masita., Safitrah, A., Nurfadillah, M., dan Setiyawati, E. 2016. Analisis kandungan gizi limbah kulit pisang kepok (Musa paradisiaca Formatypica) sebagai bahan baku kerupuk. Jurnal Biology Science \& Education, 5(1): 112-123

Purwati. 2007. Efektifitas plastik polipropilene rigid kedap udara dalam menghambat perubahan kualitas daging ayam dan daging sapi selama penyimpanan beku. Skripsi. Bogor: Fakultas Teknologi Pertanian. Institut Pertanian Bogor

SNI.01-2713-1992 Tentang Kerupuk Ikan. www.bsn.go.id. diakses tgl 1 Februari 2019

Winarno, FG. 1997. Kimia Pangan dan Gizi. Jakarta: PT Gramedia Pustaka. Jakarta

Yasin, N. 2018. Pengaruh penambahan tepung pisang pada pembuatan kerupuk. Gorontalo Agriculture Technology Journal, 1(1): 49-58

Zura, CF. 2006. Cita Rasa (Flavor). Departemen Kimia FMIPA. Medan: Universitas Sumatera Utara 